\title{
PAUL THE INTERPRETER.
}

\author{
A. J. Rowland, D.D., LL.D.
}

During our Lord's earthly life there must have been much questioning with regard to his person, teachings and work. Even his own disciples did not know in what category they should place him, nor did they understand the wider relations of his mission. It is quite evident from the narratives in the synoptic gospels that while he walked among men the manifestations he gave of his personality in word and deed presented a problem no one was able fully to solve.

After the departure of our Lord from earth the solution of this problem became still more difficult. In view of the circumstances attending his death and resurrection men could not help asking who Jesus really was? What was implied in his teachings? What was the relation of his teaching, not simply to Jewish law and prophecy, but to humanity at large? What was the significance of his life and death? What authority was there in his commands? What was the proper method by which men might be brought into fellowship with him? What assurance was there that the acceptance of his teachings would be a sufficient rule of life and receive suitable reward? These questions and many others were inevitably thrust upon the attention of all thinking men acquainted with the facts of Christ's life, death and resurrection, and created a wide and urgent demand for explanation or interpretation.

This demand was imperative and insistent. Some explanation or interpretation of Christ's person, teachings and work was needed at once. The early assembly of the followers of Christ, had a very narrow foundation upon which to build. It is very evident from the accounts given in the Acts of the Apostles that even Peter had no full or adequate conception of the out-reachings of the 
teachings and work of the crucified and risen Saviour. Almost at once parties began to be formed. There was great danger that the followers of Christ would in a short while become mere modernists of the Jewish system, and like all other modernists eventually disappear or be re-absorbed into the older forms of thought and life. If Christianity was to be what we believe Jesus meant it to be, and what it has since become, there was an insistent need of someone who would give an adequate and authoritative interpretation of our Lord and of his teachings and work.

To meet this emergency, and to give the world such an interpretation, God in his good providence called into his service the Apostle Paul. Certainly it would be difficult to find a man better fitted for so great a mission. Gifted with a keen and logical, mind, he had been trained in the best schools of his day. He knew the Mosaic law and the institutions and precepts connected with it. His connection with the Jewish race and his knowledge of the law enabled him to comprehend the full power of that law in influencing the individual and national character. His experience as a devoted member of the straitest Jewish party showed him at once the power and weakness of the law. He came into fellowship with Christ through struggle. His experience of the divine power and reality of Christ's presence and influence was overwhelming. With this experience came illumination. Added to this illumination, and growing out of it, came after long reflection, views of Christ and his mission which covered the whole realm of what is now known as Christian truth. Some of us still believe, notwithstanding the fact that many nowadays have little or no place for inspiration, that in his interpretation of the person, teachings and work of his Master, Paul, as he himself claimed, had the constant aid of the Holy Spirit. But whether this be so or not, it is true that Paul did become the interpreter of Christ's 
system, and that as far as we can see, there was no other man of his own time, or indeed of any subsequent time, more competent to act in that capacity.

Let it be understood also that Paul in his interpretation was not influenced by Greek or even by Hebrew ideas except as the latter were involved in his explanation of the relations of law and righteousness. Dr. Albert Schweitzer, in his recent volume on Paul and his interpreters, makes it plain, I think, that Paul was not at all affected, at least in the conclusions he reached, by Greek thought. "Those who hold the theory of Greek elements in Paul," says Schweitzer, "must, if they are to be consistent, also assert that he pioneered a path for the Gospel into the Hellenic world, and prepared the way for the early Greek theology. But the history of dogma bolds a different language. It has to record the fact, inconceivable as it may appear, that on the generations in which Greek dogma was taking shape Paul exercised no influence whatever. The remarkable point is that the post-apostolic writers, though they are acquainted with the works of the Apostle to the Gentiles, make no real use of them. The early Greek theology is quite independent of Paul."'

What is true of the Apostle's relation to Greek thought is equally true of his relation to Jewish ideas of the law as entertained in his day. The law was to Paul only the school-master leading to Christ-a temporary step in the divine education of the race, and in large part, if not wholly, to be superseded by the Gospel. No one can read the Epistle to the Galatians without seeing that Paul had himself not only completely out-grown the Jewish system, and haid divested himself utterly of his former Pharisaic prejudices, but that his attitude toward the Jewish conceptions of righteousness had entirely changed.

As an interpreter of the person, teachings and work of Christ, Paul, therefore, occupied a position influenced 
only by his personal relations to his Lord. He took the facts (so he himself claims) as he knew them, or as they were revealed to him or secured by him from competent sources, and put upon these facts a construction which conformed to his own judgment and experience; a judgment and experience which he at least believed to be guided and inspired from above. The conclusions he reached with regard to the person of our Lord and the nature and relations of his work Godward as well as manward were not borrowed from any other source, but were the calm and logical product of his own spirituallyillumined mind.

Of the interpretations given by the Apostle it is impossible in a paper of this size to speak at length. It must be sufficient now to say that these interpretations have thus far in the history of Christianity been accepted by much the larger part of the Christian world as satisfactory and authoritative. What Paul affirms with regard to God and his purposes, Christ and his work, the true righteousness, the province of faith, the guilt and power of sin, the sanctification of man, the work of the Spirit, the church, the future state, have generally. been believed, not only to accord with the teachings of our Lord, but to fill out and make clear many things which in the nature of the case our Lord himself could not fully assert or explain. It should be remembered always in our study of the Apostle's writings that we ourselves may not apprehend them in their full content and relations and may draw unwarranted inferences from them. Men have often done this. In the period of the Reformation, when Paul's writings found their renaissance, undoubtedly undue stress was laid on some portions of these writings to the prejudice of other portions. Modern scholarship is, however, doing much to put Paul's affirmations and arguments in their true light. No man can read a book like Principal Garvie's, "Studies of Paul and his Gospel," without the conviction that the great Apostle does give 
the best possible interpretation of the whole scheme of human salvation which our Lord came to earth to disclose and fulfil.

While, however, the majority of the Christian world accepts Paul's interpretation of the Gospel of Christ as a valid, satisfactory and authoritative statement, there are some objections which should be considered.

1. It is said that Paul deflected the original and simple Gospel of Jesus, especially in his doctrine of the Atonement. All that our Lord asks, we are told, is that men shall repent of their sins and come back to a father who ever loves and longs for them. Paul's doctrine of the Atonement makes it necessary that satisfaction be made to the divine Justice or Holiness before mere repentance can be availing.

It is sufficient to say in reply to this objection that our Lord in his earthly life could not in his teachings include the whole content of repentance and forgiveness, or the conditions which make the latter possible, though there are clear intimations that he regarded his life and death as substitutionary and sacrificial. His special thought in the parable of the prodigal son was to show men the divine attitude toward a wandering and sinful race. How a holy father can be thus gracious he does not explain. Paul does explain it, and thus meets one of the deepest and most pervasive instincts of the human heart; the feeling that for every sin some proper atonement should and must be made.

Beside this, it deserves to be said that the deflection from the primitive Gospel from which the church suffered for many centuries was not due to the Apostle's teaching. As Schweitzer has very clearly shown, the early Christian fathers and their successors did not draw their dogmatic conclusion's and distinctions from Paul, but rather, if from the Scriptures at all, from the fourth Gospel. It was the return to Paul's epistles in the 16th century which really restored the primitive Gospel and brought 
men face to face once more with God and their fellowmen. To this renewal of the study of the Apostle we owe all present social movements.

2. It is said that Paul's arguments are often defective; as, for example, the discussion in the Epistle to the Galatians regarding Abraham's two sons, and the conclusions drawn therefrom. Doubtless from our modern point of view there is ground for this objection. Analogy can hardly be regarded as a syllogism, but for the purpose Paul had in view, and considering the people for whom he ordinarily wrote, his arguments, while technically defective, were legitimate enough. The truths he desired to teach can be accepted quite apart from the arguments employed to establish them, and after all it is the truths which are of chief importance.

3. It is said that Paul was mistaken in his eschatological views, and since this is the case, cannot be relied upon in his other teachings. I presume there can be little doubt that Paul did believe in his earlier Christian experience, at least, in the speedy coming of the Lord, and the early termination of the dispensation of grace. It would seem, however, that he changed his views on this point in his later years. But, even if he was mistaken in his eschatology, we can hardly find in this fact a good reason for rejecting his interpretation on other matters. Our Lord himself, as will be seen in the synoptic Gospels, apparently predicted for himself a speedy return to earth, and the early setting up of his Kingdom. On this teaching the Apostle may have based his own eschatological views and hopes. If he was wrong, his Master was wrong also. But the fact is, neither was wrong. The picture of the last things is without perspective. The time of our Lord's coming is not definitely fixed, but, like death, is always imminent. Infinitely better was it for Paul's contemporaries, as indeed it is for all mankind, to be constantly watchful, rather than to place the great vital facts of life and of the Kingdom so far in the distance that they have no influence whatever on conduct or hope. 
4. It is said that Paul's ethics is at fault. Mistaken as he was in his eschatology, and looking as he did to a speedy termination of all things earthly, his ethics was only a sort of ad interim scheme which overlooked the broader and more vital relations of men to one another. He has nothing to say with regard to slavery, then as always a crime against the human brotherhood. He lays down no precepts affecting the problems of capital and labor. He holds out no present hope of relief or uplift for the toiling and struggling masses. He lays embargoes on woman. He fails to outline any governmental, social or educational plans for making the life men are compelled to live on the earth more tolerable and happy.

To all these, it may justly be said, I think, that very much the same strictures may be made with regard to the teaching of Jesus. So far as we have any record, he never uttered $a$ word in denunciation of the political and social slavery of his day. There is nothing in his direct teaching on the relations of capital and labor. Bad and cruel as was the Roman Government, he commanded his disciples to "render what was due to Caeser," as they rendered what was due to God. While it is evident that his heart went out in sympathy towards the oppressed and poor, he advanced no revolutionary schemes for their relief. $\mathrm{He}$ assigned no place for women beyond that in which Jewish life and custom placed her. The present or earthly life to him was apparently not one of easy conditions and happy environment, but a struggle to do and suffer the divine will-a much nobler conception of life, by the way, than that offered us by our present day economists or socialists.

Of course the explanation of the silence of Jesus and Paul in all these matters is trite and plain enough. In the larger concerns pertaining to human life they both trusted to the working out of the principles they incarnated and tanght. Their poverty ennobled and encouraged the poor. Their treatment of all men as simply 
men without regard to social standing or wealth put the entire humanity within the bounds of a common brotherhood The gradual out-working of the conduct and teachings of Paul and his Master were sure to eventuate at last in better conditions and a nobler life and a higher and more satisfactory social status for all mankind, women as well as men. It is the failure to recognize and put into practice these principles which is the primary cause of all the social disturbances and individual unhappinesses of our own day.

I think it also deserves to be said that so far as Paul is concerned his ethical teaching, while essentially the same as his Master's, affects more closely the details of human life. Surely no one can read the last four chapters of his Epistle to the Romans without being conscious of this. Surely also no heavier blow was ever dealt to human slavery than that dealt by Paul when he exhorted Philemon to regard his returned slave, Onesimus, no longer as a bond-servant, but as a brother. What better text could the most ardent Socialist ask than Paul's words to the Galatians, "There is neither Jew nor Greek; there is neither bond nor free; there is neither male nor female, for ye are all one in Christ Jesuis"? "One in Christ Jesus," let it be noted, for Paul was wise enough to know that there can be no real brotherhood or unity which does not ground itself in a religious fellowship based upon common faith and life in a common Redeemer and Lord.

May we not justly conclude, therefore, that Paul was divinely chosen and fitted to be the interpreter of the Gospel of our Lord; definitely appointed to disclose the true meaning of the person, teachings and work of our Lord, and to give answer to the profoundest questionings and cravings of the mental and moral nature of man, not simply for his own day, but for all time? The more we study Paul's writings and compare these with the teachings of Jesus, the more we will see, I am sure, 
that instead of "deflecting" the primitive Gospel, as modern scholarship sometimes affirms, from its original simplicity to a dogmatic system, Paul has, not only preserved Christianity from destruction, but has widened and buttressed it and made it a stronghold in which men may well dwell without fear of attack from any foe, philosophical, scientific or socialistic. His teachings, I believe, while perhaps not on the same level with those of his Lord, are nevertheless of divine authority, and are worthy of acceptation as a sufficient rule of faith and practice for all followers of Christ. With Principal Garvie I say, "The cry 'back to Christ' from many lips today expresses, not only appreciation of Christ himself, but also depreciation of Paul. It is often supposed that the simple Gospel of Jesus has been obscured and perverted by the Apostle to the Gentiles. The historical function of Paul in delivering the Christian church from its imminent danger of being merely a Jewish sect, and in forcing the door open for it to become a world-wide relation, is ignored. If his significance in this respect were fully recognized, would it not be impossible to suppose that the man who secured for the Gospel its widest extension was guilty of its most thorough perversion? It is at least probable that the mind that perceived most clearly the scope of the revelation of God in Christ conceived most fully the contents of that revelation. As a study of the experience of Paul will show, he himself was conscious of his absolute dependence on his intimate communion with and his loyal submission to his living Lord, and unless we are to judge him as self-deceived, or as deceiving others, we must regard his life, which was "hid with Christ in God," as a culmination of the ministry of Jesus. God was still revealing his Son in Paul. If this be so, then the antithesis so commonly assumed between the teachings of Jesus and Paul is false, and we are concerned only with different but not contradictory modes of the same manifestation." 
To this, in conclusion, may I add some words of a recent reviewer of Royce's "Problem of Christianity" "Professor Royce," he says, "renders a good service in his criticism of the view of those who hold that real Christianity requires us to get back of Paul to the parables of Jesus, and who also holds that Paul perverted the simplicity of the religion of Jesus, and that the true problem of Christianity is the elimination of the Pauline additions.' Royce says, that Jesus could not mean his teachings to be taken as the conclusive statement of the Gospel, that that teaching implied an enlargement and interpretation to be added after he had gone, and that the development which came with Paul was the necessary and foreseen expansion which was to open out the real and full meaning of the new faith." 